\title{
An Evaluation of Stocking and Regeneration Capacity of Naturally Growing Acacia gerrardii (Benth) in Central Regions of Saudi Arabia
}

\author{
N.D. Shetta ${ }^{1,2 *}$, T.S. Alshaharani ${ }^{1}$ and R.A. Nasser ${ }^{1,2}$ \\ ${ }^{1}$ Department of Plant Production, Food and Agriculture Sciences College, \\ King Saud University, Riyadh, Saudi Arabia. \\ ${ }^{2}$ Department of Forestry and Wood Technology, Faculty of Agriculture, \\ Alexandria University, Alexandria, Egypt. \\ http://dx.doi.org/10.13005/bbra/2020
}

(Received: 01 January 2016; accepted: 06 February 2016)

\begin{abstract}
The present study was carried out in central region of Saudi Arabia. The objective of the study was to evaluate the diversity, stocking and regeneration capacity of the natural growing Acacia gerrardii (Benth) in 5 sites selected from three governments namely; Huraymila', Dhurmah and Dawadmi. The sampling of Acacia species was conducted within circular sample plots. Inside each site, three sample plots were selected to determine the regeneration capacity, tree stocking and productivity. The results indicated that the growth diversity and stand structure of naturally growing Acacia gerrardii in Riyadh region varied with location. Most of the trees in locations occurred as woodlots. Dawadmi recorded the maximum tree stocking and productivity. The regeneration capacity in Huraymila' was higher whereas the least total seedling ha ${ }^{-1}$ was record at Dawadmi location. Removing trees for various purposes reduced heavily the stocking density of the trees, regeneration capacity and the chlorophyll contents in locations. The stocking density and regeneration in locations were low cause of indiscriminate cutting of trees and intensive grazing. Tree heights were below the average as a result to low stocking density and increased natural spacing between trees. Acacia gerrardii woodlots in this area require immediate intervention and protection to attain sustainability.
\end{abstract}

Key words: Central region of KSA, Growth diversity, Regeneration capacity, Stocking, Sustainability,

Forests in Saudi Arabia are concentrated in the Southwestern part of the Kingdom at Sarawat Mountains, in the South at Aseer Mountains and in the North of Kingdom at Hejaz Mountains ${ }^{1}$. Naturally growing Acacia species occur mostly as woodlots in some parts of Saudi Arabia. Acacia spp. is very important types of vegetation in Saudi Arabia as country with a very small vegetation cover and huge areas of deserts. In Saudi Arabia, the acacia communities represent the climax stage of xerophytic vegetation and generally have a high

\footnotetext{
* To whom all correspondence should be addressed. Tel.: +966-11-467-527; Fax: +966-11-467-8467

E-mail:n.shetta@yahoo.com
}

cover and low species diversity ${ }^{2,3}$

There are 15 indigenous species of Acacia widely distributed throughout Saudi Arabia that thrive in the arid and semi-arid regions. Most of these provide wood that is used as fuel and timber and form a good source of gum, tannins, and forage. In addition, they form a good habitat for the honey bee to produce good quality honey ${ }^{4}$, ${ }^{5}$. The most popular acacia species of Saudi Arabia include A. ehrenbergiana, A. tortilis, A. etbaica, A. asak, and A. gerardii. Only a few acacia species are used for firewood and charcoal production such as A. ehrenbergiana, A. tortilis and A. gerardii, while the others are a good source of browse, pole timber, gums, and tannins ${ }^{6}$. 
The Acacia populations in Saudi Arabia are threatened because of their narrow genetic diversity and geographical range, small population size and low density, extreme environmental conditions, and indiscriminate cutting of trees, the uprooting of plants and the consequent soil disturbance has caused a significant degradation of forest and rangeland in Saudi Arabia ${ }^{7,8}$. Factors that cause hindrance in the realization of Acacias' full potential need to be studied and controlled to ensure optimal harness of their regeneration potential. The efforts undertaken by the Ministry of Agriculture to reclaim forest and rangeland could be met with little or no success 9 .

Forest management needs specific knowledge of forest characteristics on which to base important management decisions. On top of the simple population characteristics such as heights, diameters, number of individuals' tree or seedlings per hectare, the stand table, i.e. the diameter distribution, is important ${ }^{10}$. Also soil seed bank is very important in vegetation maintenance, succession, and regeneration after disturbance where soil seed bank can be used to restore the vegetation at degraded sites. Also, soil seed indicates to variations in plants distribution, diversity on specific area and give an estimate of the regeneration potential after disturbance ${ }^{11}$. The leaf chlorophyll content is one of the most significant parameters related to the physiological status of plants. Estimations of chlorophyll contents and related chlorophyll parameters can be used as an index of nutrient status, physiological stress and changes in abiotic factors ${ }^{12}$.

Acacia gerrardii belongs to subgenus Acacia, which accommodates all the African Acacia species with straight spine scent stipules. Acacia gerrardii is found in Iraq, Jordan, Sinai Peninsula and the Arabian Peninsula. Acacia gerrardii was grown in many areas especially at South, Southwestern of Saudi Arabia and classified as one the most promising species cause of wide genetic variation within the species and its wide distribution are likely to be a good basis for selection for desirable traits especially in central region of Saudi Arabia. No attention was given to the natural growth of Acacia gerrardii (Benth) in the arid region of Saudi Arabia, especially under the Riyadh region conditions; the aim of the study was to evaluate the diversity, stocking and regeneration capacity of the natural growing Acacia gerrardii (Benth) under the intensive grazing and cutting in different locations at central region of Saudi Arabia as promising tree in Saudi Arabia.

\section{MATERIALSANDMETHODS}

\section{The study locations and sites}

The study was included 5 sites selected from three governments have the Acacia gerrardii (Benth) trees namely; Hurimella (86 Km North West of Riyadh City) included three sites (Assad, Thadiq1, Thadiq2), Dhurmah (60 Km West of Riyadh City) have one site name Hayssia and Dawadmy have one site namely; Musloum (360 Km West of Riyadh City) at Riyadh region in Center of Saudi Arabia during the years 2013 and 2014. Most of Acacia gerrardii (Benth) under investigation was wild grown in natural forest. The study sites in the three locations were prepared by locating the recorded coordinates for each location. Latitude, longitude and altitude of the study sites were recorded using geographic information system (GPS) (Table 1).

\section{Soil analysis}

Soil profiles were morphologically described following the terminology outlined by the Soil Survey Staff. Soil samples were collected, air dried ground gently and then sieved through a $2 \mathrm{~mm}$ sieve, the fractions less than $2 \mathrm{~mm}$ were kept for laboratory analyses. Physical and chemical analyses of soil areas were determined in Table 2.

\section{Climate of the study locations}

The locations in the Riyadh region were within the bottom margin of the arid zone according to pluviometer index of Emberger ${ }^{13}$. The sites were within the flat land zone, with elevations ranging from 600 to $930 \mathrm{~m}$. The climate was hot desert, and the mean annual temperature varied from $29^{\circ} \mathrm{C}$ to $31^{\circ} \mathrm{C}$. The mean annual humidity was ranged from $18 \%$ to $29 \%$ (Figure1).

\section{Tree sampling}

The sampling of Acacia species was conducted within circular sample plots (0.1 ha). The circular plots were defined with a plastic rope (17.8 $\mathrm{m}$ radius), and the rope was fixed to a peg at the center of the sample plot and moved approximately $360^{\circ}$. The trees outside the circle were marked with spray paint. Depending on the 
distribution and the density of trees, three sample plots were selected at each study site in Huraymila', Dhurmah and Dawadmi. Inside each sample plot, tree height, diameter at breast height (DBH), crown diameter of trees, measured with a measuring stick and averaged, and the number of seedlings were determined. The DBH was measured with a caliper. Based on these measurements, the mean DBH per hectare, the mean total Height per hectare, the basal area and tree volume per hectare, and the number of DBH per hectare were computed as indicators of forest structure and harvest sustainability.

\section{Soil seed banks}

In each sample plot, one tree was chosen randomly for determination of the seed bank. Three pairs of quadrats $(0.5 \times 0.5 \mathrm{~m})$ were sampled, one each in the north, south and east directions. For each direction, one quadrat was located at the base of the tree stem and the other was $1.0 \mathrm{~m}$ from the first one. Inside each quadrat, a soil sample was taken from a depth of $5 \mathrm{~cm}$ and placed in a fabric bag. The soil samples were sieved with 3, 5 and 8 $\mathrm{mm}$ meshes to eliminate stones, soil and other debris. The seeds were counted and categorized as healthy seeds, insect infested seeds and total seeds.

\section{Extraction and analysis of chlorophyll}

Three leaves per tree were analyzed for chlorophyll. The leaf samples were weighed and ground with $1 \mathrm{ml}$ of solvent DMF in a mortar with a pestle. The homogenate, combined from a further three washings of the pestle and mortar (each of $1.5 \mathrm{ml}$ ) with the same solvent, was centrifuged at $2500 \mathrm{rpm}$ in a bench centrifuge for $10 \mathrm{~min}$. The pellet was extracted with a further $1 \mathrm{ml}$ of solvent in a homogenizer, and the pooled supernatant were adjusted to a final volume of $8 \mathrm{ml}$. The spectrum was recorded between 750 and $600 \mathrm{~nm}$, and the major red absorption peak was automatically de-termined by the UV-VIS spectrophotometer (specto UV-2505; LABO, MED. Inc.,), with recording zeroed at $750 \mathrm{~nm}$. The $\mathrm{Chl} a, b$, and Chl $a+b$ contents in $\mu \mathrm{mol} \mathrm{L} \mathrm{L}^{-1}$ were calculated using the equations of Porra et al., ${ }^{14}$.

\section{Statistical analysis}

The statistical analysis was performed with the SAS statistical software package. The experiment was a completely randomized design. The data were analyzed for location, growth characteristics and chlorophyll content with analysis of variance (ANOVA). Means of treatments were compared with Duncan's test at the 0.05 level of probability. The data for the number of stems per tree and the number of seedlings were square root transformed before the ANOVA.

\section{RESULTSAND DISCUSSION}

\section{Growth parameters between locations}

Forest management requires precise knowledge of forest parameters on which to base important management decisions. The heights, mean diameters, and number of individual trees per hectare are primary population characteristics. Variability in growth characteristics was found between locations. Significant differences were detected for tree height, number of stems tree ${ }^{-1}$, number of seedlings $\mathrm{ha}^{-1}$, and basal area and tree

Table 1. Study areas in the Riyadh region of Saudi Arabia

\begin{tabular}{|c|c|c|c|c|}
\hline Area & Site & Coordinates & Number of sample plots & Tree species \\
\hline \multirow{6}{*}{ Huraymilla } & Assad & N. $25^{\circ} 05^{\prime} 694^{\prime \prime}$ & 3 & Acacia gerrardii \\
\hline & & E. $46^{\circ} 04^{\prime} 477^{\prime \prime}$ & & \\
\hline & Thadiq 1 & E. $45^{\circ} 57^{\prime} 257^{\prime \prime}$ & 3 & Acacia gerrardii \\
\hline & & N. $25^{\circ} 08^{\prime} 078^{\prime \prime}$ & & \\
\hline & Thadiq 2 & N. 250' $983^{\prime \prime}$ & 3 & Acacia gerrardii \\
\hline & & E. $45^{\circ} 56^{\prime} 631^{\prime \prime}$ & & $\begin{array}{l}\text { Acacia ehrenbergiana } \\
\text { Acacia tortilis subsp tortilis }\end{array}$ \\
\hline \multirow[t]{2}{*}{ Dhurmah } & Hayssia & N. $24^{\circ} 47^{\prime} 769^{\prime \prime}$ & 3 & Acacia gerrardii \\
\hline & & E. $46^{\circ} 01^{\prime} 530^{\prime \prime}$ & & \\
\hline \multirow[t]{3}{*}{ Dawadmi } & Musloum & N. $23^{\circ} 56^{\prime} 684^{\prime \prime}$ & 3 & Acacia gerrardii \\
\hline & & E. $43^{\circ} 43^{\prime} 262^{\prime \prime}$ & & Acacia ehrenbergiana \\
\hline & & & & Acacia tortilis subsp tortilis \\
\hline
\end{tabular}


volume between locations. The average tree height of $5.85 \mathrm{~m}$, crown diameter of $5.49 \mathrm{~m}$, number of stems per tree of 1.5 stems tree $^{-1}$ and diameter at breast height of $14.6 \mathrm{~cm}$ were significantly higher in Dhurmah than in Huraymila' and Dawadmi (Figure 2A and 2B).

The basal area is used as a measure of stand density and tree volume according to Ducey and Valentine ${ }^{15}$. For tree density and productivity, Dawadmi had the highest basal area and tree volume, with an average of $0.4 \mathrm{~m}^{2} \mathrm{ha}^{-1}$ and $0.7 \mathrm{~m}^{3}$, respectively (Figure 2A). Huraymila' was the exception, with tree regeneration of 257 seedlings ha $^{-1}$ (Figure 2B).

\section{Growth parameters between sites}

The data indicate that the growth parameters of the trees varied between sites. Highly significant differences were recorded for the sites in the crown diameter, number of stem per tree, number of seedlings per hector and tree Basel area. While no significant differences were found at tree height, tree diameter and tree volume. Hayssia site at Dhurmah location recoded the maximum tree height (5.86 m), tree diameter at d.b.h $(15 \mathrm{~cm})$, crown diameter (5.48 m) and number of stem tree ${ }^{-1}(1.5)$ compared with the other studied sites. On the other hand, Musloum site at Dawadmi recorded the highest tree Basel area ha-1 $\left(0.37 \mathrm{~m}^{2}\right)$ and tree volume $\mathrm{ha}^{-1}\left(0.67 \mathrm{~m}^{3}\right)$ (Table 3). The same trend was found at Assad site at Huraymilla had the greatest seedlings number ha ${ }^{-1}$ with average 395 seedling ha-1 (Table 3).

Measurement of the structural attributes of vegetation is an essential component of forest inventory. Currently, most forest inventories involve traditional methods that require intensive

Table 2. Physical and chemical characteristics of soils from the three study areas

\begin{tabular}{|c|c|c|c|c|c|c|c|c|c|c|c|c|}
\hline \multirow[t]{2}{*}{ Location } & \multirow[t]{2}{*}{ Site } & \multicolumn{3}{|c|}{$\begin{array}{c}\text { Particle size } \\
\text { distribution (\%) }\end{array}$} & \multirow[t]{2}{*}{$\begin{array}{c}\text { Soil } \\
\text { texture }\end{array}$} & \multirow[t]{2}{*}{ SP (\%) } & \multirow[t]{2}{*}{$\begin{array}{l}\mathrm{OM} \\
(\%)\end{array}$} & \multirow[t]{2}{*}{$\mathrm{pH}$} & \multirow{2}{*}{$\begin{array}{c}(\mathrm{m} \\
\mathrm{mhos} / \mathrm{cm})\end{array}$} & \multicolumn{3}{|c|}{$\begin{array}{l}\text { Mineral elements } \\
\text { (ppm) }\end{array}$} \\
\hline & & sand & silt & clay & & & & & & $\mathrm{N}$ & $\mathrm{P}$ & $\mathrm{K}$ \\
\hline \multirow{3}{*}{ Huraymilla } & Assad & 88.8 & 4.00 & 7.20 & Sand & 21.0 & 0.55 & 8.30 & 0.82 & 42.6 & 11.5 & 94.8 \\
\hline & Thadiq 1 & 72.7 & 20.0 & 7.30 & $\begin{array}{l}\text { Sandy } \\
\text { loamy }\end{array}$ & 28.6 & 1.13 & 8.30 & 1.00 & 61.6 & 17.4 & 485.8 \\
\hline & Thadiq 2 & 77.7 & 15.0 & 7.30 & $\begin{array}{l}\text { Sandy } \\
\text { loamy }\end{array}$ & 22.5 & 1.00 & 8.40 & 1.01 & 53.4 & 7.7 & 140.8 \\
\hline Dawadmi & Musloum & 79.7 & 12.0 & 8.30 & $\begin{array}{l}\text { Sandy } \\
\text { loamy }\end{array}$ & 24.3 & 0.35 & 8.40 & 1.17 & 39.2 & 4.3 & 175.9 \\
\hline
\end{tabular}

SP: Saturation Point, OM: Organic Matter, EC: Electrical conductivity

Table 3. Mean values of the growth parameters of A. gerrardii grown in different sites

\begin{tabular}{|c|c|c|c|c|c|c|c|c|}
\hline Locations & Sites & $\begin{array}{c}\text { Tree } \\
\text { Tree height } h^{-1} \\
\text { (m) }\end{array}$ & $\begin{array}{c}\mathrm{DBH} \mathrm{h}^{-1} \\
(\mathrm{~cm})\end{array}$ & $\begin{array}{c}\text { Crown } \\
\text { diameter } \mathrm{h}^{-1} \\
\text { (m) }\end{array}$ & 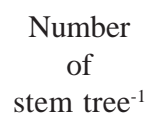 & $\begin{array}{l}\text { Number of } \\
\text { Seedling ha-1 }\end{array}$ & $\begin{array}{c}\text { Basel } \\
\text { area h-1 } \\
\left(\mathrm{m}^{2}\right)\end{array}$ & $\begin{array}{c}\text { Volume } \\
\mathrm{h}^{-1} \\
\left(\mathrm{~m}^{3}\right)\end{array}$ \\
\hline \multirow[t]{3}{*}{ Huraymilla } & Assad & 5.24ab & $13.0 \mathrm{a}$ & $4.07 \mathrm{~b}$ & $1.00 \mathrm{c}$ & 395.6a & $0.15 b$ & $0.30 \mathrm{~b}$ \\
\hline & Thadiq 1 & $5.04 \mathrm{ab}$ & $14.0 \mathrm{a}$ & 4.63ab & $1.00 \mathrm{c}$ & $92.9 \mathrm{~b}$ & $0.16 \mathrm{~b}$ & $0.32 b$ \\
\hline & Thadiq 2 & $5.23 a b$ & $12.0 \mathrm{a}$ & 5.04ab & $1.00 \mathrm{c}$ & $56.4 \mathrm{~b}$ & $0.20 \mathrm{~b}$ & $0.37 b$ \\
\hline Dhurmah & Hayssia & $5.86 a$ & $15.0 \mathrm{a}$ & $5.48 a$ & $1.50 \mathrm{a}$ & $119.0 \mathrm{~b}$ & $0.21 b$ & $0.45 \mathrm{ab}$ \\
\hline Dawadmi & Musloum & $4.55 b$ & $14.0 \mathrm{a}$ & 4.78ab & $1.25 b$ & $55.0 \mathrm{~b}$ & $0.37 \mathrm{a}$ & $0.67 \mathrm{a}$ \\
\hline
\end{tabular}

DBH: Diameter at breast height, Lowercase letters show significant differences between sites; values with the same letter are statistically similar and those with different letters are significantly different. 
Table 4. Soil seed bank at different sites in Riyadh region

\begin{tabular}{|c|c|c|c|c|}
\hline Locations & Sites & $\begin{array}{l}\text { Number of healthy seeds } \\
\text { seeds } \mathrm{m}^{-2} \text { tree }^{-1}\end{array}$ & $\begin{array}{l}\text { Number of infected seeds } \\
\text { seeds } \mathrm{m}^{-2} \text { tree }^{-1}\end{array}$ & $\begin{array}{l}\text { Total of seeds } \\
\text { seeds } \mathrm{m}^{-2} \text { tree }^{-1}\end{array}$ \\
\hline \multirow[t]{3}{*}{ Huraymilla } & Assad & $9.60 \mathrm{~b}$ & $26.0 \mathrm{a}$ & $36.8 \mathrm{a}$ \\
\hline & Thadiq 1 & $0.00 \mathrm{c}$ & $0.00 \mathrm{~b}$ & $0.00 \mathrm{~b}$ \\
\hline & Thadiq 2 & $8.28 \mathrm{bc}$ & $44.8 \mathrm{a}$ & $54.8 \mathrm{a}$ \\
\hline Dhurmah & Hayssia & $19.47 a$ & $23.2 \mathrm{a}$ & $42.8 \mathrm{a}$ \\
\hline Al-Dawadmi & Musloum & 7.20bc & $18.0 \mathrm{a}$ & $27.48 \mathrm{a}$ \\
\hline
\end{tabular}

Lowercase letters show significant differences between sites; values with the same letter are statistically similar and those with different letters are significantly different.

Table 5. Mean values of the Chlorophyll concentrations of A. gerrardii grown in different sites

\begin{tabular}{lccccc}
\hline Locations & Sites & $\begin{array}{c}\text { Chlorophyll } a \\
(\mu \mathrm{mol} / \mathrm{L})\end{array}$ & $\begin{array}{c}\text { Chlorophyll } b \\
(\mu \mathrm{mol} / \mathrm{L})\end{array}$ & $\begin{array}{c}\text { Chlorophyll } a+b \\
(\mu \mathrm{mol} / \mathrm{L})\end{array}$ & $\begin{array}{c}\text { Chlorophyll } \\
\text { Ratio }\end{array}$ \\
\hline Huraymilla & Assad & $11.43 \mathrm{a}$ & $2.47 \mathrm{ab}$ & $13.92 \mathrm{ab}$ & $4.79 \mathrm{a}$ \\
& Thadiq 1 & $8.09 \mathrm{~b}$ & $2.36 \mathrm{ab}$ & $10.45 \mathrm{c}$ & $3.70 \mathrm{~b}$ \\
& Thadiq 2 & $9.38 \mathrm{ab}$ & $2.90 \mathrm{ab}$ & $13.46 \mathrm{ab}$ & $4.09 \mathrm{ab}$ \\
Dhurmah & Hayssia & $11.33 \mathrm{a}$ & $3.42 \mathrm{a}$ & $15.86 \mathrm{a}$ & $3.83 \mathrm{~b}$ \\
Al-Dawadmi & Musloum & $9.21 \mathrm{ab}$ & $2.28 \mathrm{~b}$ & $11.49 \mathrm{bc}$ & $4.22 \mathrm{ab}$ \\
\hline
\end{tabular}

Lowercase letters show significant differences between sites; values with the same letter are statistically similar and those with different letters are significantly different.

field efforts. The sampling designs of such field visits are dependent on accuracy and precise specifications, area coverage, and the budget of the inventory ${ }^{10}$.

Basal area of a stand or tract is most useful as a first step in estimation of volume. Basal area can be used as a measure of stand density, but that use derives historically from the basal area: volume relationship, and practically from ease of measurement, rather than from any expectation of a biological or ecological functional relationship ${ }^{15}$.

A common way to measure trees is to record 'diameter at breast height', or DBH. DBH is then used to calculate tree growth, basal area, and biomass. In unmanaged forests, the structures of tree populations often vary considerably, even among stands of the same age and habitat class. Unimodal tree diameter distributions may develop, in particular, if the succession starts after a stand replacing disturbance, and regeneration occurs fairly rapidly. However, often in a disturbance event only a portion of the trees die, and the surviving trees remain as part of the living structure of the stand $^{16,17,18}$. This obviously leads to increased variability in tree sizes, and the development of multimodal, decreasing or irregular tree diameter distributions. The locations were highly degraded because of the indiscriminate cutting of trees and intensive grazing. The crown coverage in the locations ranged between 1.51-10.85 m. However, the number of seedlings ha ${ }^{-1}$ was relatively low $(0$ 630 ), probably as a result of intensive grazing and close proximity of human settlements to the forests. The average total heights of Acacia gerrardii trees at the three locations (2.0-9.3 m) were relatively low and might be attributed to the wide spacing between trees, which reduced competition for light. The DBH ranged between $26.6 \mathrm{~cm}$ and $41.0 \mathrm{~cm}$. The scarcity of large diameter trees was probably an indication of illicit harvest and overgrazing, which later resulted in extremely stunted trees. This scarcity of large diameter trees in most of the locations was a cause for concern. Our results support the conclusions of Rouvien and Kuuluvainen ${ }^{19}$ who stated that the absence of large trees would likely reduce the ability of the forest to sustain high biodiversity. Additionally, the climate had a considerable effect on the distribution of Acacia spp. The results were in agreement with 
the findings of Aref and El- Atta ${ }^{2}$ and Al- Mefarrj ${ }^{7}$ who demonstrated that climate, illicit felling, and high grazing intensity as well as fires were the most important causes for the degradation of the natural forest trees in the Asser, $\mathrm{Al}$ baha and Al Madinah regions. Acacias, in general, demand light, and when grown closely spaced, they grow more in height in search of light, which was not the case in the three locations. Currently, the maximum tree stocking and productivity were in Dawadmi, followed by Dhurmah. The regeneration of trees was the highest in Huraymila', followed by Dhurmah, whereas the fewest seedlings ha ${ }^{-1}$ were at Dawadmi. From the date it can be proposed that Dawadmi recorded the maximum stocking and productivity followed Dhurmah. The regeneration

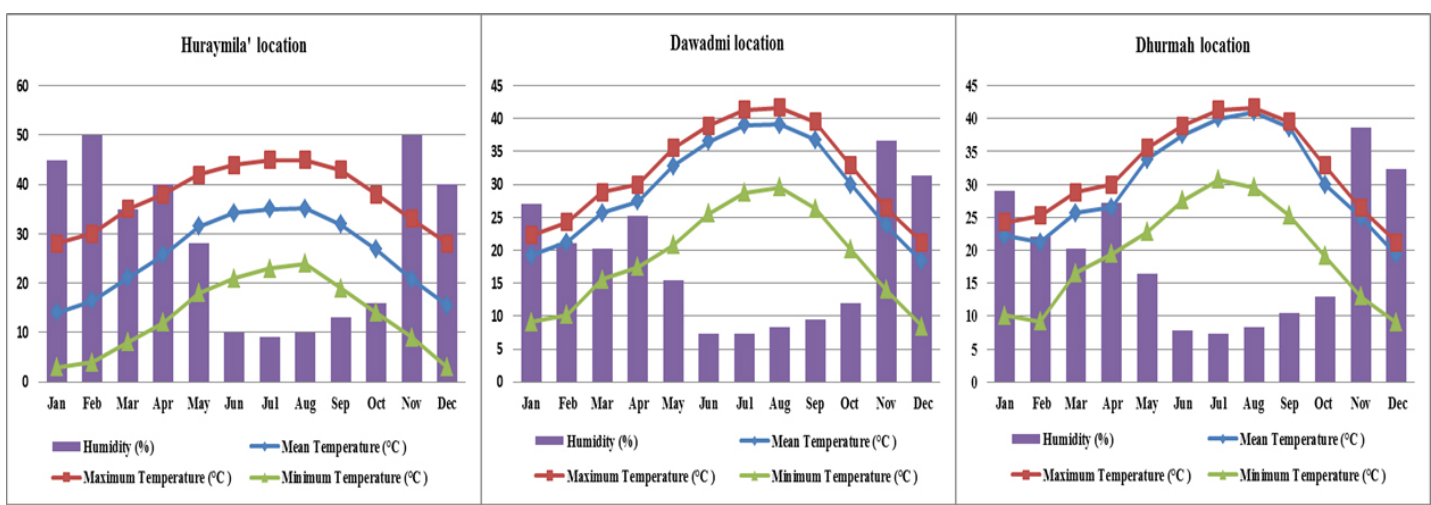

Fig. 1. The mean annual humidity and temperature of the study locations during 2013 (Source:www.weatherspark.com)
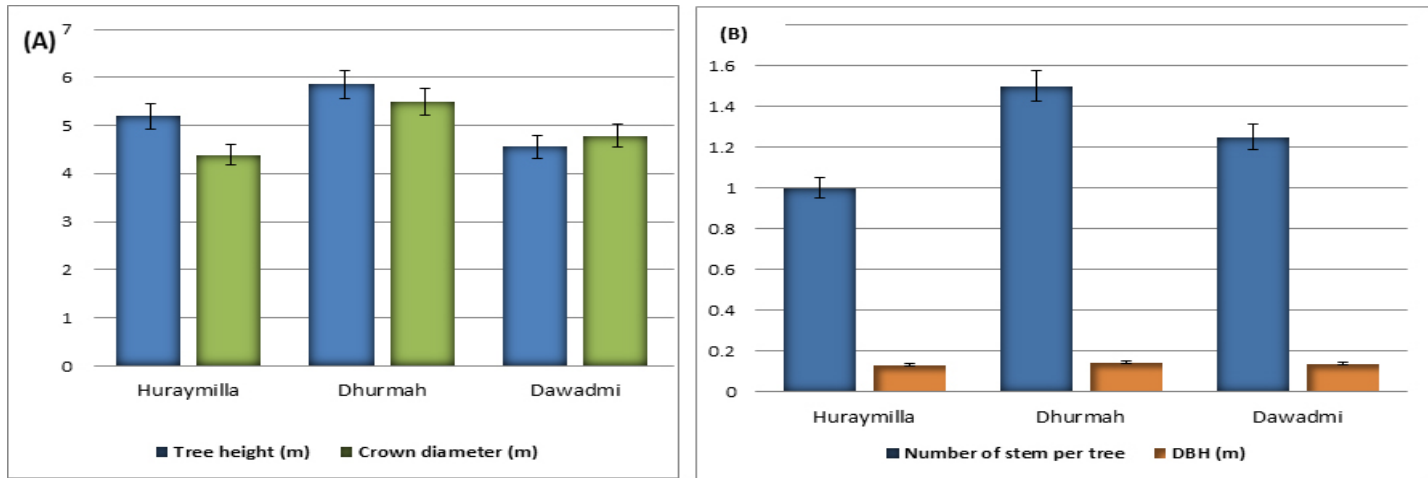

Fig. 2. Mean values of the growth parameters of Acacia gerrardii in different locations
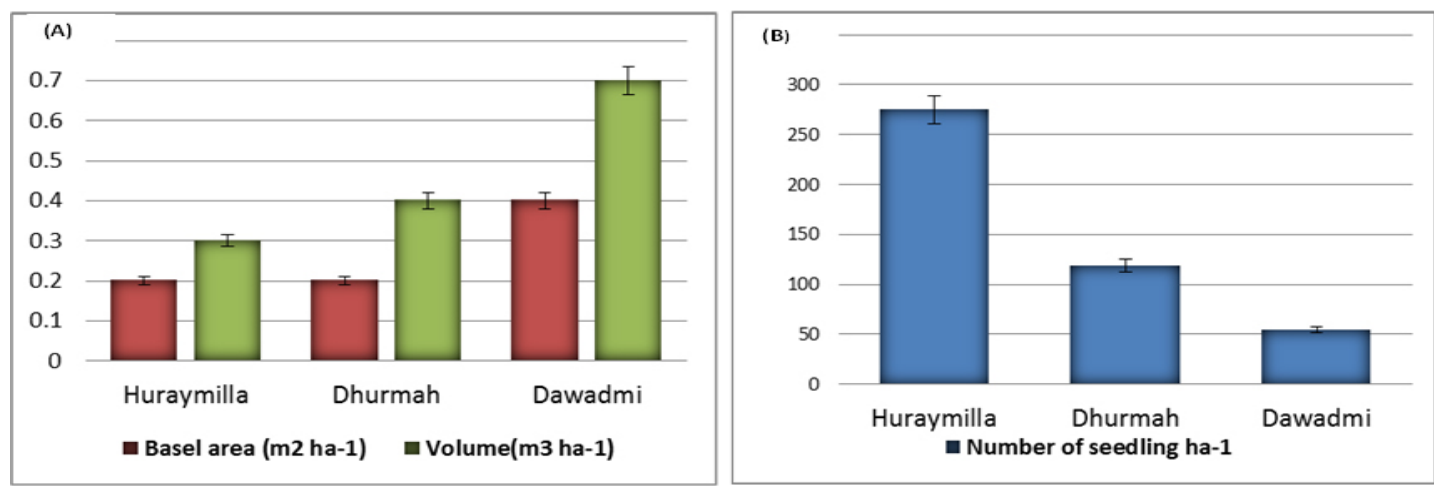

Fig. 3. Mean values of tree stocking and productivity (A) and tree regeneration (B) of $A$. gerrardii grown in different locations 
in Huraymilla was higher followed by Dhurmah whereas the least total seedling $\mathrm{ha}^{-1}$ was record at Dawadmi location.

\section{Soil seed bank between locations and sites}

The soil seed bank density was different between under and beyond the tree canopy. The densities of seeds were highest below parent tree canopies and decreased with distance beyond the canopy. The seed store per parent tree increased with tree size. The soil seed bank varied between the locations for the parameters examined. Highly significant differences were recorded for the number of healthy seeds, infected seeds and total number of seeds between locations and sites under the tree crown and distance beyond the tree crown. The mean number of healthy seeds $\mathrm{m}^{-2}$ tree $^{-1}$ was higher in Huraymila' (12.08 seeds), followed by Dawadmi (8.28 seeds), whereas the fewest mean healthy seeds were at Dhurmah (1.0 seed). For the total number of seeds $\mathrm{m}^{-2}$ tree $^{-1}$ and the number of infected seeds $\mathrm{m}^{-2}$ tree $^{-1}$, Dawadmi recorded the maximum numbers (54.8 and 44.8 seeds, respectively) compared with the other locations, and the differences were significant (Figure 4).

For the sites, Hayssia recorded the highest number of healthy seed (19.44 seeds $\mathrm{m}^{-2}$ tree $\left.^{-1}\right)$ followed by Assad ( 9.60 seeds $\mathrm{m}^{-2}$ tree $^{-1}$ ) and Thadiq2 (8.28 seeds $\mathrm{m}^{-2}$ tree $^{-1}$ ) (Table 4 ). Thadiq 2

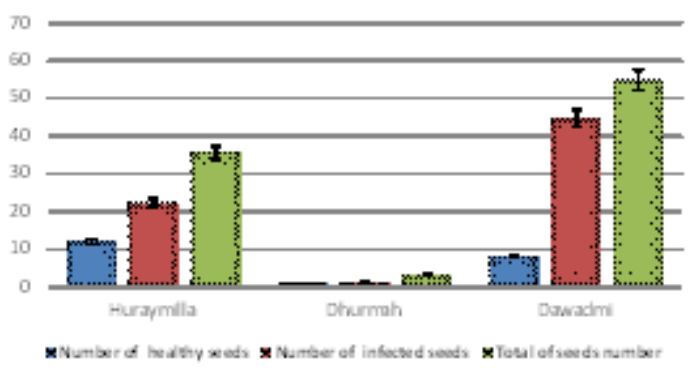

Fig. 4. Mean values of the densities of the soil seed bank of $A$. gerrardii grown in different locations

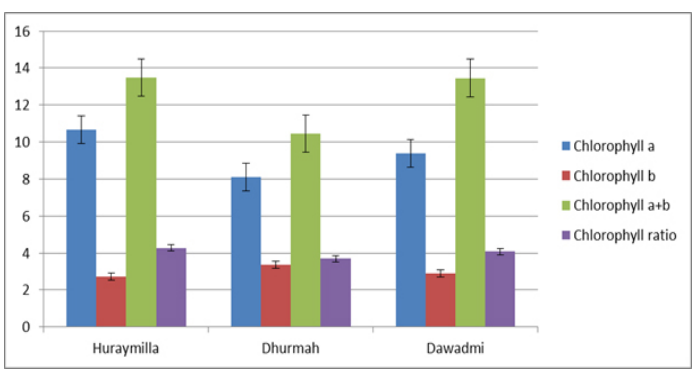

Fig. 5. Mean values of chlorophyll content of $A$. gerrardii grown in different locations at Huraymilla recorded the highest number of infected seeds and total seed number compared with the other sites. The mean values were 44.8 and 54.8 seeds $\mathrm{m}^{-2}$ tree $^{-1}$ respectively.

The result of our study indicated that, the soil seed bank densities were different between under and beyond the tree crown and canopy, the seed densities were highest below parent tree canopies and decreased with distance beyond the canopy, and total seeds stored per parent tree increased with tree size. These results were consistent with the findings of Witkowski and Garner $^{20}$; Sternberg et al.,21 and Funes et al., ${ }^{22}$ in studies on Acacia tortilis, A. nilotica and Dichrostachys cinerea. The seed bank richness and density increased with altitude. The relatively warm conditions at the lower altitudes might increase the activity of seed predators, whereas the relatively cold climate at the higher elevations might favor the formation of a persistent seed bank. Additionally, the densities of seeds decreased in areas far from the trees. By contrast, Argaw $^{23}$ found that $A$. seyal accumulated seeds in the soil seed bank in areas far from the parent tree. The position of seeds in the soil and the soil particle size, structure and chemistry affected the seed quantity, quality and germination ${ }^{24}$. The majority of viable seeds were found in the first centimeter and then declined with depth, whereas the emergence of seedlings depended on depth of seed burial because of environmental factors such as light, oxygen, temperature, and moisture ${ }^{25}$. Most of the infected seeds in the study were infected by beetles and could not germinate, which was in agreement with the findings of Abdullah and Abulfatih ${ }^{26}$; Abulfatih ${ }^{27}$ and Erenst et al. ${ }^{28}$ who found that seeds of native acacia species were heavily infested with the bruchid beetle (Bruchidius), reducing the natural regeneration of the species in Saudi Arabia. Moreover, a seed bank can be affected by annual seed production, dispersal, and predation. For example, African acacias, e.g., Acacia albida produce large amounts of seeds per large tree, which are dispersed by wind or ungulates ${ }^{29}$. The analysis of the soil seed bank indicated that a decrease in the number of seeds in soil of the studied locations might reflect the intensive grazing and degradation on the growth of trees. These results were consistent with the findings of Osem et al., ${ }^{30}$ and Defalco et al., ${ }^{31}$ who found that surface 
disturbance affected seed viability of Mojave Desert species; viable seeds of perennials were rare in undisturbed areas (3- 4 seeds $\left.\mathrm{m}^{-2}\right)$ and declined to $<1$ seed $\mathrm{m}^{-2}$ within disturbed sites, emphasizing that surface disturbances can have a variable effect on the condition of the soil surface in arid lands.

Generally, in Saudi Arabia, the removal of trees for various purposes greatly reduced the density of the species and affected regeneration, which might lead to an irreversible change in the function of these woodlands.

Chlorophyll content between sites and locations

Chlorophyll is the green molecule in plant cells responsible for energy fixation in photosynthesis. In the present study, the analysis of variance for Acacia gerrardii detected differences between the locations for chlorophyll content. Chlorophyll $a$ and $a+b$ were significantly different, whereas chlorophyll $b$ and the chlorophyll ratio were not significantly different. The Huraymila' acacias had the highest chlorophyll $a$ and $a+b$ contents and chlorophyll ratio with averages of 10.66 and $13.50 \mu \mathrm{mol} \mathrm{L} \mathrm{L}^{-1}$ and 4.79, respectively. Dhurmah had higher chlorophyll $b$ content (3.36 $\left.\mu \mathrm{mol} \mathrm{L}^{-1}\right)$ than the other two locations (Figure 5). The same trends were found between the sites and chlorophyll contents, the chlorophyll $a$ and $a+b$ gave highly significant between the sites, while the chlorophyll $b$ and chlorophyll ratio were not significant. Assad at Huraymilla was record highest chlorophyll $a$ and chlorophyll ratio with averages $11.43 \mu \mathrm{mol} \mathrm{L}^{-1}$ and 4.79 respectively. On the other hand, Hayssia at Dhurmah was record highest chlorophyll B (3.42 $\left.\mathrm{mol} \mathrm{L}^{-1}\right)$ and chlorophyll AB (15.68 $\left.\mu \mathrm{mol} \mathrm{L}^{-1}\right)$ (Table 5).

Chlorophyll is a key molecule in photosynthesis and has value as a biomarker in ecosystems studies. The removal the trees and grazing decreased the chlorophyll content, observations consistent with the findings of Gnojek, ${ }^{32}$; Pukacki and Rozek ${ }^{33}$ and Alahverdi and Savabieasfahani ${ }^{34}$ who demonstrated that increasing environmental degradation threatened the tree ecosystems. The removal of overstory trees caused a drastic increase in light intensity and temperature fluctuations near the ground and a rise in the ground water table, and the relative humidity decreased during the day. A decrease in chlorophyll content can be a result of viral infection, nitrogen deficiency, abnormal humidity, soil salinity, or drought conditions Yatsenko et al., ${ }^{35}$; Khayyat et al., ${ }^{36}$ and Baker and Rosenqvist ${ }^{37}$. Our observations showed that the chlorophyll contents varied between locations and were affected by the conditions of environmental degradation caused by tree removal and intensive grazing.

\section{CONCLUSIONS}

Removing trees for various purposes greatly reduced the stocking density of the trees, the capacity for regeneration and the contents of chlorophyll in the three locations. The stocking densities and regeneration capabilities in the locations were low cause of indiscriminate cutting of trees and intensive grazing. The tree heights were below average because of low stocking densities and increased natural spacing between trees. Currently, in the locations studied, Acacia gerrardii may play important roles in the environment and provide non-wood products as well as wood products. The Acacia gerrardii woodlots in Saudi Arabia require immediate intervention and protection to attain sustainability.

\section{ACKNOWLEDGMENTS}

The authors thank the College of Food and Agricultural Research Center and the Deanship of Scientific Research, King Saud University, Saudi Arabia for supporting this work.

\section{REFERENCES}

1. El Atta H., \& Aref, I., Effect of terracing on rainwater harvesting and growth of Juniperus procera Hochst. International Journal of Environmental Science and Technology, 2010; 7(1): 59.

2. Aref, I. M.,\& El Atta, H., Growth performance and stand structure of some Acacia spp. in south western Saudi Arabia. International Journal Plant Animal Environmental Sciences, 2010; 3(2): 64.

3. Shaltout, K., \& Mady, M., Analysis of raudas vegetation in central Saudi Arabia. Journal of Arid Environments, 1996; 34(4):441.

4. Chaudhary, SA. Acacia and other genera of Mimosoideae in Saudi Arabia. Ministry of agriculture and water, Riyadh, Saudi Arabia, 
1983.

5. Aref, I. M., Elkhalifah, F., \& El-Juhany, L. I., A dendrological key for identification of Acacia species growing in Saudi Arabia and Northern Sudan. Journal of King Abdulaziz University: Meteorology, Environment and Arid Land Agriculture Sciences, 2003; 14: 87.

6. Nasser, R.A., Al-Mefarrej, H.A., Abdel-Aal, M.A.,\& Hegazy, S.S., Chemical and mechanical properties of Melia azedarach mature wood as effected by primary treated sewage-effluent irrigation. American-Eurasian Journal of Agriculture and Environment Sciences, 2010: 697.

7. Al-Mefarrej, H., Diversity and frequency of Acacia spp. In the regions on the Kingdom of Saudi Arabia. African Journal of Biotechnology, 2012; 11(52): 11420.

8. Al-Rowaily, S L., Rangeland of Saudi Arabia and the tragedy of commons. Rangelands, 1999; 21(3): 27.

9. El-Juhany, L., Forestland degradation and potential rehabilitation in southwest Saudi Arabia. Australian Journal of Basic and Applied Sciences, 2009; 3(3):2677.

10. Ducey, M. J., Sampling trees with probability nearly proportional to biomass. Forest Ecology and Management, 2009; 258: 2110.

11. Ghermandi, L., Seasonal patterns in the seed bank of grassland in North-Western Patagonia. Journal of Arid Environments, 1997; 35(2): 215.

12. Fernando, S., Gonz'alez-Gil, A., Gonz'alezMolina, M. E., Mediavilla, S., \& Escudero, A., Estimation of chlorophyll in Quercus leaves using a portable chlorophyll meter: effects of species and leaf age. Annals of Forest Science, 2010; 67: 108.

13. Emberger, L., Consideration Complementaires au Sujet des recherches, bioclimatologiques et Phytoqeoqraphiques, Ecoloqiques in travauy de botanique et Ecologie. Masson , Paris, 1971; pp 29.

14. Porra, R. J., Thompson, \&W. A., Kriedemann, P. E., Determination of accurate extinction coefficients and simultaneous equations for assaying chlorophylls $a$ and $b$ extracted with four different solvents: verification of the concentration of chlorophyll standards by atomic absorption spectroscopy. Biochimica et Biophysica Acta, (BBA) Bioenergetics, 1989; 975(3): 384.

15. Ducey, M. J., \&Valentine, H. T., Direct sampling for stand density index. Western Journal of Applied Forestry, 2008; 23 (2): 78.

16. Agee, J.K., The landscape ecology of western fire regimes. Northwest Science (special issue)
1998; 24-34.

17. Franklina, J.F., Spiesb, T.A., Van Pelta, R., Careyc, A. B., Thornburghd, D. A., Rae D. Berge, Lindenmayerf, D.B., Harmong, M. E., Keetona, W.S., Shawh, D C., Biblea, K., \& Cheni, J., Disturbances and structural development of natural forest ecosystems with silvicultural implications, using Douglas-fir forests as an example. Forest Ecology and Management, 2002; 155: 399-423.

18. Lampainen, J., Kuuluvainen,T., Wallenius, T. H., Karjalainen, L., \& Vanha-Majamaa, I., Longterm forest structure and regeneration after wildfire in Russian Karelia. Journal of Vegetation Science, 2004; 15: 245-256.

19. Rouvinen, S., \& Kuuluvainen, T., Tree diameter distributions in natural and managed old Pinus sylvestris-dominated forests. Forest Ecology and Management, 2005; 208: 45.

20. Witkowski, E. T., \& Garner, R. D., Spatial distribution of soil seed banks of three African savanna woody species at two contrasting sites. Plant Ecology, 2002; 149(1): 91.

21. Sternberg, M., Gutman, M., Perevolotsky, A., \& Kigel, J., Effects of grazing on soil seed bank dynamics: an approach with functional groups. Journal of Vegetation Science, 2003; 14: 375.

22. Funes, G., Basconcelo, S., Díaz, S., \&Cabido, M., Seed bank dynamics in tall-tussock grasslands along an altitudinal gradient. Journal of Vegetation Science, 2003; 14:253.

23. Argaw, M., Teketay, D., \&Olsson, M., Soil seed flora, germination and regeneration pattern of woody species in an Acacia woodland of the Rift Valley in Ethiopia. Journal of Arid Environments, 1999; 43: 411.

24. Traba, J., Azcárate, F. M., \&Peco, B., From what depth do seeds emerge? A soil seed bank experiment with Mediterranean grassland species. Seed Science Research, 2004; 14: 297.

25. Baskin, C.C., \& Baskin, J. M., Seeds, Ecology, Biogeography and Evolution of Dormancy and Germination. San Diego, Academic Press, 2001; 666.

26. Abdullah, M. A. R., \& Abulfatih, H. A., Predation of Acacia seeds by bruchid beetles and its relation to altitudinal gradient in southwestern Saudi Arabia. Journal of Arid Environments, 1995; 29 (1): 99.

27. Abulfatih, H. A., Seed germination in Acacia species and their relation to altitudinal gradient in south western Saudi Arabia. Journal of Arid Environments, 1995; 31(2): 171.

28. Ernst, W. H., Tolsma, D. J., \&Decelle, J. E., Predation of seeds of Acacia tortilis by insects. Oikos, 1989; 54: 294. 
29. Marchante, H., Freitas, H., \&Hoffmann, J. H., Seed ecology of an invasive alien species, Acacia longifolia (Fabaceae), in Portuguese dune ecosystems. American Journal of Botany, 2010; 97 (11):1780.

30. Osem, Y., Perevolotsky, A., \&Kigel, J., Size traits and site conditions determine changes in seed bank structure caused by grazing exclusion in semiarid annual plant communities. Ecography, 2006; 29(1): 11.

31. Defalco, L., Esque, A., Kane, T. C., \&Nicklas, M. B., Seed banks in a degraded desert shrubland: Influence of soil surface condition and harvester ant activity on seed abundance. Journal of Arid Environments, 2009; 73(10): 885.

32. Gnojek, A. R., Changes in chlorophyll fluorescence and chlorophyll content in suppressed Norway spruce (Picea dies (L.) Karst.) in response to release cutting. Trees, 1992; 6: 41.
33. Pukacki, P. M., Rozek, E. K., Effect of drought stress on chlorophyll: a fluorescence and electrical admittance of shoots in Norway spruce seedlings. Trees, 2005; 19: 539.

34. Alahverdi, M., Savabieasfahani, M., Seaweed and Chlorophyll as Biomarkers of Metals in the Persian Gulf, Iran. Bulletin of Environmental Contamination and Toxicology, 2012; 89: 501.

35. Yatsenko,V., Cifarelli, C., Boyko, N., Pardalos, P. M., Modeling and Device Development for Chlorophyll Estimation in Vegetation. Advances in Modeling Agricultural Systems, 2009; 421.

36. Khayyat, M., Tehranifar, A., Davarynejad, G. H., \&Sayyari-Zahan, M. H., Vegetative growth, compatible solute accumulation, ion partitioning and chlorophyll fluorescence of 'Malas-e-Saveh' and 'Shishe-Kab' pomegranates in response to salinity stress. Photosynthetica, 2014; 52(2): 301.

37. Baker, N. R., Rosenqvist, E., Applications of chlorophyll fluorescence can improve crop production strategies: an examination of future possibilities. Journal of Experimental Botany, 2004; 55:1607. 